\title{
Service Recovery Based on Perceived Justice: A Study on Locus Attribution
}

\author{
Yolanda Masnita Siagian ${ }^{1} \&$ Hermien Triyowati ${ }^{1}$ \\ ${ }^{1}$ Faculty of Economics, Trisakti University in Jakarta, Indonesia \\ Correspondence: Yolanda Masnita Siagian, Faculty of Economics, Trisakti University in Jakarta, Jln. Kyai Tapa \\ Grogol, Jakarta Barat, 14440, Indonesia. E-mail: priyono.unu_sidoarjo@yahoo.com
}

Received: March 31, 2015

Accepted: April 27, 2015

Online Published: June 20, 2015

doi:10.5539/ijbm.v10n7p99

URL: http://dx.doi.org/10.5539/ijbm.v10n7p99

\begin{abstract}
The purpose of this study is to close the gap from previous studies regarding the failure recovery services do not consider the locus attribution. Changes in the service process to the era of SSTs (Self Service Technologies), increasing the cause of the failure is not only companies but also can be derived from the customer. This study seeks to examine the compatibility between failure and recovery that can be perceived as fair.

By using experimental or experimental method, using a study design with one-way between subject by 3 (three) factors experimental / independent variables, namely: 2 (type of failure: failure process vs. outcome failure) x 2 (locus attribution: firm vs. customer) x 6 (recovery strategies: Compensation, No Compensation, Immediate Response Speed, Delay Response Speed, Apology Present, Absent Apology). The results showed that the recovery is done by locus attribution greatly affects perceived justice
\end{abstract}

Keywords: type of failure, locus attribution, perceived justice

\section{Introduction}

Ones must have ever experienced service failures, such as an unfriendly receptionist when welcoming guests in the hotel or an unfriendly restaurant waiter when taking orders. The inhospitable will make customers feel disappointed, and will further feel much disappointed and angry if the company responds to the disappointment by giving compensation in the form of cash as the recovery effort. The failure due to unfriendly service is more on psychological factors, while the recovery by giving money in return is more on the economic; so that the recovery effort is not appropriate and will be fatal for the company. Customers would be expecting an apology statement and confession from the waiter, than the money given.

In contrast, customers also feel disappointed if the service failure occurs resulting in economic losses, such as errors in goods delivery service, or when in a restaurant, a mismatching order. It turns out that the company only recovers services to psychological factors by apologizing. Of course, this does not eliminate customer frustration. Therefore, it is important to know the types of failure, so that the selection of appropriate recovery strategies can be done.

When errors or service failures occur, people tend to look for the cause of the failure. Humans will further evaluate the cause of the incident at the time the results are dissatisfying or unsuccessful, instead of in the time of the incident when the results are satisfying or successful (Weiner, 1985, 1986, 2000). Heider $(1946,1958)$ introduced Attribution Theory, which is a set of cognitive theories that explains why an event can occur and how the explanation will affect the evaluation and one's behavior (Swanson \& Kelley, 2001). Weiner (1980) explained that there are three major factors or dimensions of service failure attributions: controllability, stability, and locus (location of the cause).

Controllability is consumer perception of the degree of company's ability to control the incidence of service failures. For example, how much control of the company at the time it finds a customer smoking in no-smoking room, whether the company is able to reprimand the customer. Stability is the frequency of failure occurrences, whether the failure is routine or temporary. The failure in regular frequency indicates that the company does not make good policies and procedures. Locus (location of the cause) is consumer perception of which side the cause of the failure, whether the failure is caused by the service provider (company) or by the customer.

Current developing studies on Attribution Theory only discuss about controllability and stability (Huang, 2008; 
Hess, 2008), while the third factor-locus (location of cause) is not much discussed. Hess (2008) stated that locus attribution is an important factor in the occurrence of a failure, but researchers always do not examine this factor. Because until now, customers have a perception that the whole process is the service provider's responsibility, especially on services that use a full service, services with very low customer engagement.

In addition, when the failure occurs, customers rarely acknowledge that it is caused by them. This is due basically if a failure occurs, people do not want to admit guilt (Weiner, 1980). Likewise, when an error occurs on the services using an electronic tool which most of the services performed by the customer, probability of the failure is caused by the customer. Therefore, the actual locus attribution which occurs in the customer may happen, location or the fault location can be on the company or on the customer.

Based on the review of reasoning, it can be concluded that service failures do not only due to the service provider but also may be caused by the customer. The service failures are caused by the customer, such as: (i) the customer is ashamed to admit that she/he is not quite adept in operationalizing technology; (ii) the customer does not understand the commands which are typically using a foreign language; (iii) the customer does not complete the whole process (Forbes, 2008); (iv) the customer is not careful; (v) the customer is careless by not keeping secrets with its use (Kompas, 2010).

The service failure caused by the customer (customer locus) makes an evaluation of service recovery change. First, the recovery evaluation with justice theory at the time of recovery is based on the theory of perceived justice. This theory explains that people will feel fair when they perceive a balance or correspondence between the results received (output) and the input (Adams, 1965; Aurier \& Martin, 2007; Martin-Ruiz \& Rondan-Cataluria, 2008). The balance between inputs and outputs becomes biased when the failure is caused by the customer. The resulting output is highly dependent on the customer's input; customers have a great responsibility towards the final result of services (Ennew \& Binks, 1999).

Second, selection of the recovery from service failure is selected based on the theory of resource exchange. Bagozzi (1975) stated that in exchange process the customer will be satisfied when in the exchanging the resources are the same or similar resources that have different categories (Foa et al., 1993). Efforts to handle the service failure are a form of exchange as well, the treatment will be considered satisfactory when the resources exchanged have the same values and categories. The condition will be different when the failure is caused by the customer. With the service process highly involving the customer, it makes the customer's expectation for recovery change. Customers have a great responsibility to the final result of service. The failure occurs should become a risk borne by the customer (Ennew \& Binks, 1999).

The main formulation to be studied in this research is to close the gap of the previous studies on the recovery of service failure that do not consider the locus attribution. Changes in the service process to the era of SSTs (Self Service Technologies) increase causes of the failure not only on the company but also on the customer. This study examines the conformity between failures and recoveries so it can be perceived to be fair.

\section{Research Model and Hyphoteses}

Service recovery is performed after service failure happens. It is identified as one of the keys to achieve customer loyalty. Successful and satisfying recovery efforts are the key to customer retention (Duffy et al., 2006). There are three parts that determine customer satisfaction towards treatments of the failure (service recovery), namely: (i) type of failure, (ii) locus attribution, and (iii) recovery strategies. It will be then evaluated with perceived justice that has three dimensions, so that the customer is expected to feel fair when getting service failure recovery.

The first part, type of failure is results expected at each stage of the service are not achieved. Types of failure consist of outcome failure and process failure (McColl-Kennedy et al., 2009). Outcome failure is the failure that is received actually by the customer. It means that organizations or service providers cannot fulfill the basic service needs, or they cannot fulfill the service core. Process failure is defective/deficient way in delivering service core.

The next (second) part is locus attribution. Weiner (1980) defined locus (location of the cause) as consumer perception of the location of the failure causes, whether the failure is caused by the service provider (firm) or by the customer. Location of the failure causes is indicated by the responsible party in the event (Bitner \& Hubbert, 1990). If a greater responsibility is on the service provider as indicated by the service provider's involvement in service process more than the customer's, it refers to firm-based locus, and vice versa. If the customer's involvement in service process is greater than the provider's, it is customer-based locus. 


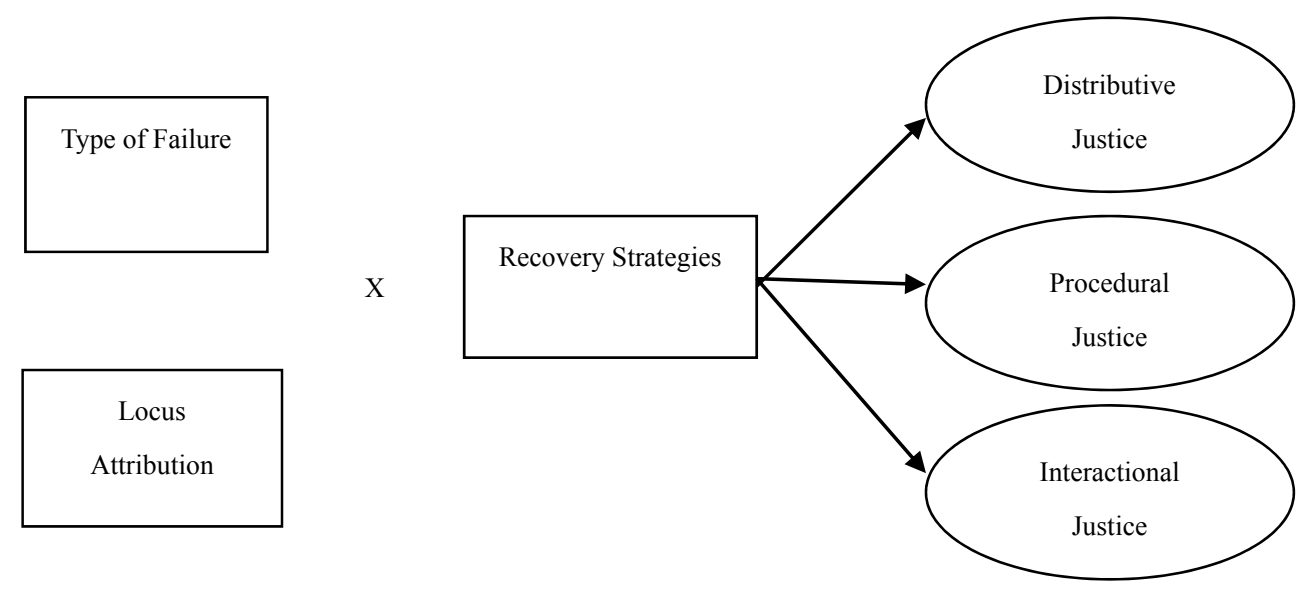

Figure 1. Conceptual framework

The third part is recovery strategies. Smith et al. (2002) identified that recovery strategies is what the organization does as a response to service failures. Service recovery strategies with the design: 2 (Compensation vs No Compensation) x 2 (Response speed: Immediate vs Delay) x 2 (Apology: Present vs Absent). Hence, there are 6 recovery strategies to be tested.

\subsection{Effect of Failure Context and Recovery Strategies on Distributive Justice}

Service failure is defined as mistakes, problems, or errors that occur in service delivery (Bitner \& Hubbert, 1990). There are certain aspects in delivering the services that do not meet customer expectations (Smith \& Bolton, 2002) stated that service failure may result in loss impacts for customers in a variety of forms. First, service failure utilitarian is the failure resulting in economic losses, such as money, time, or objects. Second, service failure symbolics is the failure of psychological and social resources, such as status, respect, and empathy. In evaluation, customers tend to feel comfortable and give greater value on the same resources than on different resources at the time of the exchange (Foa \& Foa, 1974). It is in accordance with the resource exchange theory. Therefore, in failure treatment and service recovery customers will be satisfied with the recovery according to the type of failure that occurs.

Outcome failure is the failure of what actually is received by the customer. The company or the service provider cannot fulfill the basic service needs or the service core. Outcome failure causes economic losses, such as loss of money, time, or objects; it is also called utilitarian loss. Therefore the recovery is economic compensation.

There are several recovery efforts. Recovery strategies that are manifested in the economic form are compensation. In social exchange theory, it is explained that distributive justice relates to the allocation of costs and benefits in order to achieve fairness in exchange relation (Adams, 1965; Deutsch, 1975). When recovery service is performed, the perception of distributive justice explains how resources are allocated and perception of the results of the exchange (Adams, 1965; Deutsch, 1975). Economic loss and economic recovery emphasize more on the final result as a recovery strategy that can be used when one party feels unfair in exchange relation due to service failure. It means the perception of distributive justice will be increasingly perceived when the recovery strategy in the form of economic compensation emphasizes on the final result. So that, the presumption arises:

H1: In firm locus, distributive justice has a greater effect (positive) when compensation is given when a failure occurs in the outcome than when a failure occurs in the process.

Service failure can be a diversion for the company and there will be more diversions if no service recovery performed. In other words, if the failure occurs and the recovery is not performed, the company has made two mistakes (Johnston \& Fern, 1999). However, not all service failures should be recovered, especially if the cause of the failure is on the customer (Harris, Mohr, \& Bernhardt, 2006; Forbes, 2008). When a failure occurs, the customer will automatically search for the cause of the error. The failure can be caused by the company, the customer, or a combination of both. Customers who have a very high participation in the process and delivery of services will have a degree of guilt greater as the failure occurs (Yen, Gwinner, \& Su, 2004). This happens because in the process and the delivery of such services, most of the service activities are carried out by the customer. 
The failure occurring due to the customer will change expectations of the recovery effort, that the customer has a great responsibility to service results. The failure is the customer's risk and should be borne by the customer (Ennew \& Binks, 1999). Attribution theory explains that humans process information rationally (Folkes, 1988). Results of one's activities are influenced by previous events. So that, the presumption arises:

H2: In customer locus, distributive justice has a greater effect (positive) when no compensation applies than when compensation applies in both the outcome and the process as the failure occurs.

Based on social exchange theory, justice is closely connected with how to allocate costs and profits, companies must be able to provide justice in transaction (Adams, 1965; Deutsch, 1975; Sweeney \& Webb, 2007; Lam \& Lau, 2008). Distributive justice as one dimension of justice perceptions concerns with results of the effort done to customer recovery. If a service failure occurs, customers expect to get compensation (Robbins, 1996). When the customer feel disappointed because of the failure and there are time and money spent by the customer, the service provider must balance it by giving compensation.

The situation may be inappropriate, that the cause or the location of the failure can change the perception of justice for customers. When the failure is caused by the customer (customer locus), the risk of failure should be borne by the customer. Therefore, when the failure actually causes loss of costs and time, it is properly considered fair viewing from the final result of recovery efforts. This case is in accordance with the distributive justice theory. However, when the cause of the failure is on the customer, then the loss will be borne by the customer (Weiner, 1980). This condition is not beneficial for the customer. Companies which are responsible to all of their services will continue to be responsible for the process and the results that occur.

Hua (2009) stated that one of the requirements of online banking transaction can be accepted by the customer is the safety. The feeling will be obtained by the customer if the company is responsive and quickly responds to customer complaints. Thus, the final result of recovery expected by the customer is not in the form of economic compensation from the company. The emphasis is more on the company's responsiveness and response indicating that the company is still responsible, even if the error is on its customer. So that, the presumption arises:

H3: In customer locus, distributive justice has a greater effect (positive) when the response speed is given when the failure occurs in both the outcome and the process.

\subsection{Effect of Failure Context and Recovery Strategies on Procedural Justice}

Another stage of services is process. Process is interaction between service providers and customers. This stage explains how the services are produced (Schoderbek, Schoderbek, \& Kefalas, 1990). Service production cannot be separated from production and consumption, then the customer must continuously interact with individuals who provide the service. Moreover, the customer is directly influenced by service in production process. Ease of access, availability, honesty, friendly and having a desire to answer any question are the aspects of quality in process dimension.

Stages of the process are also potential for service failure. Process failure is deficient or insufficient means in delivering the service core. Consequences received by the customer in process failure are service failure symbolics, which are failures of psychological and social resources, such as status, respect, empathy (Smith \& Bolton, 2002). If the service failure causes loss of the customer's emotions or feelings, the recovery is more in terms of symbolic exchange including psychological or social resources (Bagozzi, 1975).

A recovery strategy showing psychological or social resource recovery and recovering customer's emotions or feelings is response speed. Response speed is customer's responsiveness and waiting period as the customer complains and gets service recovery. The response speed of recovery significantly affects the customer evaluation (Gilly \& Gelb, 1982; Hart, Heskett, \& Sasser, 1990).

Procedural justice is the justice perceived from the process used to determine the distribution and reward or result. This justice is associated with procedures implemented by the company for service recovery to customers who complain (Tax et al., 1998). The failure is due to insufficient way of delivering the core of services, causing losses on the emotions or feelings of the customer. The emphasis of service recovery is on the process and procedures of the company. So that, the presumption arises:

H4: In firm locus, procedural justice has a greater effect (positive) when the response speed is given when the failure occurs in the process than when the failure occurs in the outcome.

Forms of loss experienced by the customer due to the service failure are utilitarian and symbolic (Smith \& Bolton, 2002). Resource exchange theory (Brinberg \& Wood, 1983; Foa et al., 1993) outlined that the customer 
tends to feel comfortable and gives a greater value when the exchange is the same resources than when the one of the resources is different.

The pattern of exchange changes, customer expectations for recovery have different reactions when the failure is caused the customer. The suitability of resource exchange between loss and recovery does not apply, because when the customer gets economic losses the company does not have a policy to recover the loss. Inequity occurs if the exchange process is not beneficial to both parties; the company is disadvantaged, that it should bear the customer's fault. The company's efforts are to establish procedures, rules, and regulations that protect the customer. Good procedures will build customer confidence (Hua, 2009).

Procedural justice (Thibaut \& Walker, 1975) is the perception of justice relating to procedures applied by the company for service recovery to customers who make complaints. A fair procedure covers three essential elements: (i) the company taking responsibility for the service failure, (ii) any complaint quickly dealt with starting from the employee first contacted by the customer, (iii) and system flexibility and also taking into account individual circumstances and feedback from customers regarding the final outcome they expect. So that, the presumption arises:

H5: In customer locus, procedural justice has a greater effect (positive) when the response speed is given than the compensation and apology as the failure occurs in both the outcome and the process

Service failure caused by the company (firm locus) carries a greater emotional impact than the failure caused by the customer (customer locus) (Yen, Gwinner, \& Su, 2004). Therefore, expectations of the recovery in firm locus are also bigger. In other words, the company has more responsibility. So that, the presumption arises:

H6: Procedural justice is much perceived when immediate response speed is given when the failure occurs in firm locus than when the failures occurs in customer locus.

\subsection{Effect of Failure Context and Recovery Strategies on Interactional Justice}

Service failure at the stage of the process (process failure) is symbolic service failure. That is failure of psychological and social resources, such as status, respect, empathy (Smith \& Bolton, 2002). If the service failure causes loss of the customer's emotions or feelings, the recovery is more in terms of symbolic exchange including psychological or social resources (Bagozzi, 1975). The recovery to do is psychological or social resource recovery, which is to recover customer's emotions or feelings. The strategy that can be done is apology, which is a statement of apology as an award of one's self-esteem acknowledgement (a social resource) in transaction relation (Walster, Berscheid, \& Walster, 1973). The statement of apology from service providers communicated in politeness, honesty, sincerity, seriousness and showing empathy to customers who experience service failure will be evaluated by the customer in service recovery (Hart et al., 1990).

Apology is delivered by the company to the customer. It means there are interactions between the company and the customer. Thus, interactional justice perception is formed by the interpersonal interaction of service recovery received by the customer from the company. So that, the presumption arises:

H7: In firm locus, interactional justice has a greater effect (positive) when the apology is given when the failure occurs in the process than when the failure occurs in the outcome.

Statements of confession from service providers that is communicated in politeness, honesty, sincerity, seriousness and showing empathy to customers who experience service failure in the form of apology (Hart, et al., 1990) does not need to be performed on condition that the failure caused by the customer. If the apology is performed by the company, then the company indirectly admits that the failure is caused by the company. The cause of the error must be placed on the right position. If the failure is caused by the customer, the company does not need to make an apology. Everyone will think rationally, in accordance with the situation of failure (Chung-Herrera \& Goldschmidt, 2004). So that, the presumption arises:

H8: In customer locus, interactional justice has a greater effect (positive) when an absent apology is given than a present apology when the failure occurs in both the outcome and the process.

\section{Respondent and Research Procedures}

Criteria for study participants were women and men aged 20-40 years, with at least high school education background. Researchers assume that the ordinary educated participants using technology, and utilize technology as a convenience. In addition, the participant is selected participants who are familiar with and have knowledge about banking products and a customer of a bank of at least more than a year, a savings of less than USD $1 \mathrm{M}$ or not including special customers, as well as on-line service users, especially users of Automated Teller (ATM). This meant that the conditions of service failure, recovery measured in the dependent variable is not influenced 
by the views of not responsive and not technology also special because customers have savings in large amounts so received special services but respondents answer a list of questions because it is influenced by manipulation framework given in this research. Profile of respondents shown in Table 1.

Table 1. Participant prfile $(\mathrm{N}=728)$

\begin{tabular}{|c|c|c|}
\hline Description & Amount & Percentage \\
\hline \multicolumn{3}{|l|}{ Gender } \\
\hline - $\quad$ Man & 415 & 57,1 \\
\hline - Woman & 313 & 42,9 \\
\hline \multicolumn{3}{|l|}{ Age } \\
\hline - $\quad<20$ Years & 110 & 15,2 \\
\hline - $\quad 20-30$ Years & 613 & 84,2 \\
\hline - $\quad>30$ Years & 5 & 0,5 \\
\hline \multicolumn{3}{|l|}{ Banking is used } \\
\hline - $\quad \mathrm{BCA}$ & 332 & 45,7 \\
\hline - $\quad$ Mandiri & 230 & 31,5 \\
\hline - $\quad \mathrm{BNI}$ & 52 & 7,1 \\
\hline - $\quad$ Others & 114 & 15,7 \\
\hline \multicolumn{3}{|c|}{ Lastuseof bankingservices } \\
\hline - $\quad 1$ week & 8 & 1,1 \\
\hline - $\quad 1$ month & 317 & 43,5 \\
\hline - 1 year & 403 & 55,4 \\
\hline \multicolumn{3}{|c|}{ Most often, the purpose of usingbankingservices } \\
\hline •Business & 416 & 57,1 \\
\hline •Other & 312 & 42,9 \\
\hline \multicolumn{3}{|c|}{ In thelast 3 monthsthe frequency ofusingservices } \\
\hline$\bullet<10$ times & 609 & 83,7 \\
\hline •10-20times & 110 & 15,2 \\
\hline$•>20$ times & 9 & 1,1 \\
\hline \multicolumn{3}{|c|}{ Durationbecome customersof bankingservices } \\
\hline$\bullet<1$ Year & 198 & 27,2 \\
\hline$\cdot 1-2$ Years & 221 & 30,4 \\
\hline$\cdot>2$ Years & 309 & 42,4 \\
\hline
\end{tabular}

This research consists of two stages by using an open questionnaire and structured questions. The first stage was to dig and screen respondents' experience. Respondents were asked to imagine one of banking services which they have visited, then to write the name of the place on the questionnaire. Furthermore, to explore the respondents' experience to the place, they were given some questions about the experience, such as the last time they visited the place, the type of transaction made at last visit, and frequency of their visits. Later, screening the participants was conducted. Respondents must have proper educational background, get used to using technology, are not including in special customers, and are on-line service users especially users of the Automated Teller Machine (ATM) as well.

The second stage was the implementation of the research. Respondents got a scenario that describes type of failure, locus of attribution, and recovery strategies in accordance with the cells. Each group received different scenes. The scenes of type of failure and locus attribution would be checked with several questions of the questionnaire about probabilities of the service failure likely to occur. So that, the scene of service failure expected in the card was likely to occur. Furthermore, respondents received a profile of 5 recovery strategies as follows: compensation, response speed, apology, initiation, no response. Then, the respondents would evaluate the recovery strategies given the company, whether the strategies would fulfill perceived justice by using a structured questionnaire.

\section{Results and Discussion}

Based on the results of hypothesis test on the respondents with each cell ( 24 cells) participated by 35 participants, however, after the manipulation check, the amount of participants who are considered feasible to be processed further is 728 data. The results show that $\mathrm{H} 3$ to $\mathrm{H} 7$ are supported by data, while $\mathrm{H} 1, \mathrm{H} 2$, and $\mathrm{H} 8$ are not 
supported by data. The results are shown in the table follows.

Table 2. Results of hypothesis test

\begin{tabular}{|c|c|c|c|c|c|c|c|c|}
\hline \multirow{2}{*}{\multicolumn{2}{|c|}{$\begin{array}{l}\text { Statistical } \\
\text { Hypothesis }\end{array}$}} & & \multicolumn{2}{|c|}{$\begin{array}{c}\text { Levene's Test for Equality of } \\
\text { Variance }\end{array}$} & \multicolumn{3}{|c|}{$\mathrm{t}$-Test for Equality } & \multirow[t]{2}{*}{ Conclusion } \\
\hline & & & $\mathrm{F}$ & $\mathrm{Sig}$ & $\mathrm{t}$ & $\mathrm{df}$ & Sig & \\
\hline \multirow{2}{*}{\multicolumn{2}{|c|}{ H1 }} & Equal variances assumed & 4.025 & 0.049 & -1.591 & 174 & 0.113 & \multirow{2}{*}{$\begin{array}{l}\text { H1 not supported by } \\
\text { data }\end{array}$} \\
\hline & & Equal variances not & & & -1458 & 54.475 & 0151 & \\
\hline \multirow{2}{*}{\multicolumn{2}{|c|}{$\mathrm{H} 2$}} & EVA & 0.414 & 0.522 & -0.49 & 174 & 0.625 & \multirow{2}{*}{$\begin{array}{l}\text { H2 not supported by } \\
\text { data }\end{array}$} \\
\hline & & EV not assumed & & & -0.554 & 60.992 & 0.581 & \\
\hline \multirow{2}{*}{\multicolumn{2}{|c|}{$\mathrm{H} 3$}} & EVA & 2.428 & 0.124 & 2.098 & 174 & 0.037 & \multirow{2}{*}{ H3 supported by data } \\
\hline & & EV not assumed & & & 1.89 & 55.563 & 0.064 & \\
\hline \multirow{2}{*}{\multicolumn{2}{|c|}{$\mathrm{H} 4$}} & EVA & 0.202 & 0.655 & 2.037 & 174 & 0.043 & \multirow{2}{*}{ H4 supported by data } \\
\hline & & EV not assumed & & & 2.503 & 53.533 & 0.015 & \\
\hline \multirow{2}{*}{\multicolumn{2}{|c|}{ H5 }} & EVA & 5.283 & 0.025 & 1.622 & 174 & 0.107 & \multirow{2}{*}{ H5 supported by data } \\
\hline & & EV not assumed & & & 1.61 & 45.339 & 0.004 & \\
\hline \multirow{2}{*}{\multicolumn{2}{|c|}{ H6 }} & EVA & 3.188 & 0.08 & 3.627 & 174 & 0 & \multirow{2}{*}{ H6 supported by data } \\
\hline & & EV not assumed & & & 3.469 & 49.077 & 0.001 & \\
\hline \multirow{2}{*}{\multicolumn{2}{|c|}{$\mathrm{H} 7$}} & EVA & 0.202 & 0.655 & 2.098 & 174 & 0.037 & \multirow{2}{*}{ H7 supported by data } \\
\hline & & EV not assumed & & & 0.554 & 60.992 & 0.581 & \\
\hline \multirow{2}{*}{\multicolumn{2}{|c|}{$\mathrm{H} 8$}} & EVA & 5.283 & 0.025 & 2.037 & 174 & 0.043 & \multirow{2}{*}{$\begin{array}{l}\text { H8 not supported by } \\
\text { data }\end{array}$} \\
\hline & & EV not assumed & & & 0.777 & 55.563 & 0.064 & \\
\hline
\end{tabular}

Distributive Justice, either in firm or customer locus (H1 \& H2), has no difference. This suggests that economic loss and recovery do not emphasize only on the final result of recovery as a strategy that can be used when one party feels unfair in exchange relation due to service failure. In customer locus (H3) the final result of recovery expected by the customer is not in the form of economic compensation from the company. The emphasis is more on the company's responsiveness and response indicating that the company is still responsible, even if the error is on its customer.

Procedural justice is strongly perceived by the customer (H4, H5, H6). A fair procedure includes three essential elements. The elements are the company taking responsibility for the service failure, any complaint quickly dealt with starting from the employee first contacted by the customer, and system flexibility and also taking into account individual circumstances and feedback from customers regarding the final outcome they expect.

Interactional justice only applies to firm locus (H7). While in customer locus (H8), it is not perceived. It means that the interaction between companies and customers done by declaring an apology from the service provider communicated in politeness, honesty, sincerity, seriousness and showing empathy for the customer is performed only on service failure caused by the company.

Service failure and service recovery as exchange; Bagozzi (1975) stated that a process involved in the creation and completion of the formation of exchange relation becomes basic subject of marketing. The concept of exchange starts from the primary process and the dynamics of exchange relation, including tensions and conflicts that occur in marketing transaction. Service recovery arises as a result of the completion of the exchange due to pressures of the service failure. The failure directly causes activities of the recovery process. Each exchange occurs may be evaluated as a positive/negative or successful/not successful series. Service recovery is organization's attempt to correct the service failure, so that the customer assessment to service management becomes positive and she/he is eager to continue the exchange relation.

Customer satisfaction underlies the customer in making commitment to the service provider and is often reflected as a continuity subscription to the same service provider. Satisfaction of the service recovery by providers must fulfill the concept of justice. Evaluation of the recovery that has been performed will be considered effective if it is perceived to be fair.

Distributive justice is defined as the perception of justice in the form of tangible outcomes (Blodget et al., 1993). Perceived from the number and allocation of rewards or outcomes between individuals (Robbins, 1996), this justice relates to the result of efforts done for customers in the form of recovery allocation of benefits and costs (Deutsch, 1985). In H1 and H2, it can be seen that participants who receive electronic banking services do not 
emphasize service recovery only on the final result. It is seen from those two hypotheses which are not supported by data. It means that there is no difference in the perception of justice by using any kind of failure recovery strategies both in firm and customer locus. However, distributive justice is perceived when the recovery used is the recovery strategy of response speed. This is seen from the result of $\mathrm{H} 3$ which is supported by data.

Procedural justice is the justice perceived from the process used to determine the distribution and reward or result. This justice relates to rules, policies, and procedures applied by the company for service recovery to customers who make complaints. A fair procedure covers three essential elements. They are (i) the company taking responsibility for the service failure, (ii) any complaint quickly dealt with starting from the employee first contacted by the customer, (iii) and system flexibility and also taking into account individual circumstances and feedback from customers regarding the final outcome they expect. In H4, H5, and H6, the three are supported by data, showing that participants strongly consider the rules, policies, and procedures implemented.

Interactional justice is as interpersonal treatment received during the recovery process. Communication between employees and customers is very important. Explanations, efforts to communicate, honesty, politeness, and showing empathy are elements of interactional justice. In H7, it is proven and supported by data, while in $\mathrm{H} 8$ it is not supported by data. It means that when a service failure is caused by the company ( $\mathrm{H} 7)$, participants understand that the failure is not enough to be recovered only through communication. However, when the failure is caused by the customer (H8), in which the error is caused by her/himself, then the customer needs communication and further explanation about the process of banking services.

\section{Suggestions for Future Research}

As any other studies, there are weaknesses and limitations in this study. The limitations are then to be recommendations and suggestions for future research. Limitations of this study can be elaborated in some issues. First, the design used in the study is cross-sectional design, so that participants' behavior changes from time to time cannot be explained. The behavior of participants observed in this study allows biased interpretation because the participants would answer only according to psychological state at the time. It will then have an impact on the possible answers given can be situational and temporary. For example, the participants before taking part of the experiment were in high emotional condition due to external factors, they potentially or likely would say different things when the conditions were relatively stable. Therefore, it is suggested in future research to analyze the development of participants with time series data which are commonly known as design research with panel data. Additionally, in designing multiple choice questions this research is not able to use the same number of words for each option. Further studies are expected to consider the design of multiple choice questions with same number of words. Thus, there will be no biased responses arising from the length of sentences on multiple choice questions.

Second, the evaluation of service recovery is participants' perception on perceived justice, which in this study is subjective (perceptual) and non-financial. Therefore, it relatively cannot describe satisfaction objectively. In various literatures, the debate on measurement of objective versus subjective satisfaction and/or financial versus non-financial satisfaction is the debate that has not had a solution. Basic references used by studies apply subjective measurement in consideration of the difficulty in obtaining actual satisfaction data (objective) since these data are time series, such as reduced levels of complaints and service recovery costs. This has implications for research dominance in the domain of marketing to apply subjective measurement of customer satisfaction based on the participants' judgment (Oliver \& Swan, 1989; Goodwin \& Ross, 1992; Weun, Beatty, \& Jones, 2004). Moreover, in general, companies certainly pursue service recovery in hopes of obtaining customer retention (Duffy, Miller, \& Bexley, 2006), and to minimize costs towards customer rejection and negative Word Of Mouth (Seawright \& DeTienne, 2008). Whereas, this study only examines up on customer satisfaction, thus suggestion for future research is to see the impact of service recovery on customer retention and WOM.

\section{References}

Adams, J. S. (1965). Inequity In Social Exchange. In L. Berkowitz, (Ed.), Advances in Experimental Social Psyhology (vol. 2, pp. 267-299). New York: Academic Press.

Aurier, P., \& Martin, B. S. (2007). Perceived Justice and Consumption Experience Evaluations: A Qualitative and Experimental Investigation. International Journal of Service Industry Management, 18(5), 460-471.

Bagozzi, R. P. (1975). Marketing as Exchange. Journal of Marketing, 39, 32-39.

Bagozzi, R. P. (1979). The role of measurement in theory construction and hypothesis testing: Toward a holistic model. In O. C Ferrell, S. W, Brown, \& C. W. Lamb (Eds.), Conceptual and theoritical development in marketing (pp. 15-33). Chicago: American Marketing. 
Bitner, M. J., \& Hubbert, A. R. (1990). Evaluating Service Encounters: The Effects of Physical Surroundings and Employee Responses. Journal of Marketing, 54(April), 69-82.

Blodget, J. G., Hill, D. J., \& Tax, S. S. (1997). The Effects of Distributive, Procedural, Interactional Justice, on Postcomplaint Behavior. Journal of Retailing, 73(2), 185-220.

Brinberg, D., \& Ronald, W. (1983). A Resource Exchange Theory Analysis of Consumer Behavior. Journal of Consumer Research, 10(December), 330-338.

Christopher, M., Payne, A., \& Ballantyne, D. (2002). Relationship Marketing: Creating Stakeholder Value. Oxford: Elsevier Butterworth-Heinemann.

Chung-Herrera, Beth, G., Nadav, G., \& Dan, K. D. (2004). Customer and employee views of critical service incidents. Journal of Services Marketing, 18(4), 241-254.

Colquitt, J. A. (2001). On The Dimensionality of Organizational Justice: A Construct Validation Measure. Journal of Applied Psychology, 86(3), 386-400.

DelVecchio, D., Krishnan, H. S., \& Smith, D. C. (2007). Cents or percent? The effects of promotion framing on price expectations and choice. Journal of Marketing, 71(3), 158-170.

Deutsch, M. (1975). Equity, Equality, and Need: What determines, Which Value Will be Used as the Basis of Distributive Justice. Journal of Social Issues, 31(3), 137-149.

Deutsch. (1985). Distributive justice: A social Psychological Perspective. New Haven, CT: Yale University Press.

Duffy, J. A. M., Miller, J. M., \& Bexley, J. B. (2006). Banking Customers' Varied Reactions to Service Recovery Strategies. The International Journal of Bank Marketing, 24(2/3), 112-132.

Emerson, R. (1976). Social Exchange Theory. In A. Inkeles, J. Colemen, \& N. Smelser (Eds.), Annual Review of Sociology. Palo Alto, CA: Annual Reviews.

Ennew, C. T., \& Binks, M. R. (1999). The Impact of Participative Service Relationships on Quality, Satisfaction and Retention: An Exploratory Study. Journal of Business Research, 46, 121-132.

Fitzsimmons, J., \& Mona, J. F. (2004). Service Management: Operation, Strategy and Information Technology (4th ed.). New York, NY: Irwin McGrawHill.

Foa, K., Tornblom, E. B., Foa, D. J., \& Converse, Jr. (1993). Introduction: Resource Theory in Social Psychlogy, In Uriel G. F., John Converse, Jr., Kjell Y., Tormblom Dan Edna, \& B. Foa. (Eds.), San Diego Resource Theory: Explorations and Applications (pp. 1-10). CA: Academic Press.

Foa, U. G., \& Edna, B. F. (1974). Social Structures of The Mind. Springfield, IL: Charles C Thomas.

Folkes, V. S. (1988). The avaiability heuristic and perceived risk. Journal of Consumer Research, 15(June), 13-23.

Folkes, V. S., Susan, K., \& Dan, J. L. G. (1987). A Field Study of Causal Inferences and Consumer Reaction: The view from airport. Journal of Consumer Research, 13(March), 534-539.

Forbes,L. P. (2008). When something goes wrong and no one is around: Non-internet self service technology failure and recovery. Journal of Service Marketing, 22(4), 316-327.

Forbes, L. P., Andrea, L., Dixon, D., \& Rosann, L. S. (2003). Attributions and Behavioral Intentions of Inexperienced Salespersons to Failure: An Empirical Investigation. Journal of the Academy of Marketing Science, 31, 459-467.

Gilly, M. C., \& Gelb, B. D. (1982). Post-Purchase Consumer Processes and the Complainig Consumer. Journal of Consumer Research, 9(December), 323-328.

Harari, O. (1992). Thank Heaven For Complainers. Management Review, 81(January), 59-60.

Harris, K. E., Grewal, D., Mohr, L. A., \& Bernhardt, K. L. (2006b), Consumer response to service recovery strategies: the moderating role of online versus offline environment. Journal of Business Research, 59(4), 425-431.

Hart, C. W., Heskett, J. L., \& Sasser, Jr. W. E. (1990). The Profitable Art of Service Recovery. Harvard Business Review, 68(July/August), 148-156.

Heider, F. (1946). Attitudes and cognitive organization. Journal of Psychology, 21, 107-112. 
Heider, F. (1958). The Psychology of Interpersonal Relations. New York, NY: John Wiley \& Sons.

Hess, R. L. (2008). The impact of firm reputation and failure severity on customer's responses to service failures. Journal of Service Marketing, 22(5), 385-398.

Hirschman, R. (1977). Relative Effects of Bogus Physiological Feedback and Control Stimuli on Autonomic and Self Report Indicants of Emotional Attribution. Personality and Social Psychology Bulletin, 3(2), 270-275.

Hocutt, M. A., Bowers, M. R., \& Donovan, D. T. (2006). The Art of Service Recovery: Fact orFiction? Journal of Service Marketing, 20(3), 199-207

Huang, W. H. (2008). The impact of other custoner failure on service satisfaction. International Journal of Service Industry Managament, 19(4), 623-636.

Johnston, R. L., \& Fern, A. (1999). Service Recovery Strategics For Single and Double Deviation Scenarios. The Service Industries Journal, 19, 69-82.

Kompas. (2010). Anjungan Tunai Mandiri. Barometer.

Lam, L. W., \& Lau, D. C. (2008). Work Climate and Customer Satisfaction: The Role of Trust in The Retail Context. Journal of Management and Organization, 14, 141-154.

Levesque, T., \& McDougall. G. (2000). Service Problems and Recovery Strategies: An Experiment. Canadian Journal of Adminitrative Science, 17(1), 20-37.

Martin-Ruiz, D., \& Rondan-Cataluria, F. J. (2008). The Nature and Consequences of Price Unfairness in Services: A Comparison to Tangible Goods. International Journal of Service Industri Management, 19(2), 325-352.

Mattila, A. S. (2001). The Effeciveness of Service Recovery in A Multi Industry Setting. Journal of Service Marketing, 15(7), 583-596.

Mattila, A. S. (2006). The Power of Explanations in Mitigating The Ill-Effects of Service Failures. Journal of Service Marketing, 20(7), 422-428.

McColl-Kennedy, J. R., Petterson, P. G., Smith, A. K., \& Brady, M. K. (2009). Customer Rage Episodes: Emotions, Expressions and Behavior. Journal of Retailing, 85(2), 222-37.

Mohr, L. A., \& Mary, J. B. (1995). The Role of Employee Effort in Satisfaction with Service Transaction.Journal of Business Research, 32(3), 239-252.

Robbins, P. S. (1996). Organizational Behavior: Concept, Controversies, Application (7th ed.). Prentice Hall Inc, New Jersey.

Schoderbek, P. P., Schoderbek, C. G., \& Kefalas, A. G. (1990). Management Systems: Conceptual Considerations. Irwin, oston, MA.

Seawright, K. K., DeTienne, Kristen, B., Bernhisel, M. P., \& Larson, C. H. (2008). An Empirical Examination of Service Recovery Design. Journal of Marketing Intelligence and Palnning, 26(3), 253-274.

Sindhav, B., Holland, J., Rodie, A. R., Adidam, P. T., \& Louis, G. P. (2006). The Impact of Perceived Fairness on Satisfaction: Are Airport Security Measures Fair? Does It matter? Journal of Marketing Theory and Practice, 14(4), 323-335.

Smith, A. K., \& Bolton, R. N. (2002). The Effect of Customers' Emotional Responses to Service Failures on Their Recovery Effort Evaluations and Satisfaction Judgements. Journal of Academy of Marketing Science, $30(1), 5-23$.

Spreng, R. A., Harrel, G. D., \& Mackoy, R. D. (1995). Service Recovery: Impact on Satisfaction and Intentions. Journal of Services Marketing, 9(1), 15-23.

Swanson, S. R., \& Kelley, S. W. (2001). Attribution and Outcomes of The Service Recovery Process. Journal of Marketing Theory and Practice, 9(4), 50.

Sweeney, J. C., \& Webb, D. A. (2007). How Functional, Psychological, and Social Relationship Benefits Influence Individual and Firm Commitment to The Relationship. Journal of Business and Industrial Marketing, 22(7), 474-488.

Tax, S. S., Brown, S. W., \& Chandrashekaran, M. (1998). Customer Evaluations of Service Complaint Experiences: Implications for Relationship Marketing. Journal of Marketing, 62(April), 60-77.

Thibaut, J., \& Laurens, W. (1975). Procedural Justice: A Psychological Analysis. Hillsdale, NJ: Lawrence 
Erlbaum.

Vargo, S. L., \& Lusch, R. F. (2004). Evolving to a new dominant logic for marketing. Journal of Marketing, $68,1-17$.

Weiner, B. (1980). A Cognitive (attribution)-emotion-action model of motivated behavior: An analysis of judgement of help-giving. Journal of Personality and Social Psychology, 39, 186-200.

Weiner, B. (1985). An attributional theory of achievement motivation and emotion. Psychological Review, 92, 548-573.

Weiner, B. (1986). An Attributional Theory of Motivation and Emotion. New York: Springer-Verlag.

Weiner, B. (2000). Intrapersonal and interpersonal theories of motivation from an attributional perspective. Educational Psychology Review, 12, 1-14.

Weun, S., Beatty, S. E., \& Jones, M. A. (2004). The Impact of Service Failure Severity on Service Recovery Evaluations and Post-Recovery Relationship. Journal of Service Marketing, 18(2), 133-146.

Yen, H. R., \& Gwinner, K. P. (2004). The impact of customer participation and service expectation on locus attribution following service failure. International Journal of Service Industry Management, 15(1), 7-26.

\section{Copyrights}

Copyright for this article is retained by the author(s), with first publication rights granted to the journal.

This is an open-access article distributed under the terms and conditions of the Creative Commons Attribution license (http://creativecommons.org/licenses/by/3.0/). 